\title{
TanDEM-X12m Sayısal Yükselti Verisine Dayalı Toprak Erozyonu Tespiti (Rusle)
}

\section{Determination of Soil Loss Based on the TanDEM-X12m. Digital Elevation Model}

\author{
Aydoğan AVCIOĞLU1 ${ }^{1}$, Cihan BAYRAKDAR² (i), Erol SARI ${ }^{3}$ (i), Tuğçe Nagihan ARSLAN KAYA ${ }^{3}$ (1) \\ 'İstanbul Teknik Üniversitesi, Avrasya Yer Bilimleri Enstitüsü, Jeodinamik Programı, İstanbul, Türkiye \\ ${ }^{2}$ İstanbul Üniversitesi, Edebiyat Fakültesi, Coğrafya Bölümü, İstanbul, Türkiye \\ ${ }^{3}$ İstanbul Üniversitesi, Deniz Bilimleri ve İşletmeciliği Enstitüsü, Deniz Jeolojisi ve Jeofiziği Ana Bilim Dalı, İstanbul, Türkiye
}

ORCID: A.A. 0000-0001-7814-0554; C.B. 0000-0001-5542-700X; E.S. 0000-0002-4037-9305; T.N.A.K. 0000-0003-2655-1436

\section{Öz}

Toprak dünya üzerinde en önemli doğal kaynaklardan biridir. Son elli yıl içerisinde toprağın degradasyonunu belirleme adına dünya çapında yoğun bir çaba sarf edilmektedir. Bu çalışma da Karadağ’ın (Fethiye) güneyinde Akçay Havzası'nda RUSLE yöntemi ile toprak kaybını hesaplayan ve Sayısal Yükselti Modeli (SYM) verilerini yöntem kapsamında karşılaştıran bir bakış açısı ortaya koymaktadır. RUSLE yöntemi, topoğrafik (LS), iklimsel (R), bitki örtüsü (C), toprak erodobilite (K), toprak koruma yöntemleri (P) gibi parametreleri esas alarak çalışma Coğrafi Bilgi Sistemleri (CBS) yardımıyla alanda meydana gelen toprak kaybını tespit edebilmektedir. Akçay Havzası'nda toprak kaybını elde edebilmek adına, TanDEM-X12m SYM verisi kullanılmıştır, ALOS12.5m ve SRTM30m SYM verileri ile de karşılaştırılmıştır. Toprak kaybının alansal dağııımı, eğim dereceleri ( $r=0.62)$ ve $R$ faktör ile pozitif bir ilişkiye sahiptir. Akçay Havzası'nda güneyden kuzeye kısa mesafede $(15 \mathrm{~km}$ ) yükselti arttıkça, yağış ve akış bununla beraber artmaktadır. Akçay Havzası dar ve derince yarılmış V şekilli vadilerle karakterize olmaktadır ve bu durum sonucunda, LS faktörün kısa mesafede artması, erozyonu hazırlayıcı en önemli faktör olduğunu göstermektedir. Yapılan

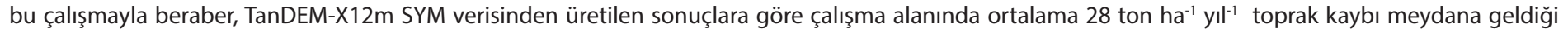
tespit edilmiştir.

Anahtar kelimeler: Toprak Kaybı, Rusle, TanDEM-X12m SYM

\section{ABSTRACT}

Soil is one of the most important natural resources in the world. Determination of soil degradation has been widely attempted all over the world in the last 50 years. This study provides a perspective of comparing the digital elevation model (DEM) in terms of the Revised Universal Soil Loss Equation (RUSLE) model, which calculates soil loss in Mountain Karadağ - Akçay Basin. RUSLE comprises the topographic (LS), climatic (R), vegetation (C), soil (K), and support practice $(\mathrm{P})$ parameters. To evaluate soil loss in the Akçay Basin, TanDEM-X12m. DEM was used and compared with ALOS12.5m and SRTM30m. DEM. Distribution of soil loss has a positive correlation with slope degree $\left(R^{2}=0.62\right)$ and rainfall and runoff factor $(R)$. As the elevation increases in the short range $(15 \mathrm{~km})$ from south to north in Akçay Basin, the rainfall and runoff increase together with elevation. The tributaries of the trunk river (Akçay) were characterized by a narrow and incised V-shaped valley, and this gave rise to increase in the LS factor in the short range. This phenomenon shows that the LS factor is one of the most important factors with regard to triggering factors. According to the TanDEM-X12m-based DEM, the mean annual soil loss is 28 ton $\mathrm{ha}^{-1} \mathrm{ya}^{-1}$ from the basin.

Keywords: Soil Loss, Rusle, TanDEM-X12m DEM

Başvuru/Submitted: 02.06.2020 • Revizyon Talebi/Revision Requested: 15.06.2020 • Son Revizyon/Last Revision Received: 25.08 .2020 • Kabul/Accepted: 05.09.2020 - Online Yayın/Published Online: 16.12 .2020 


\section{EXTENDED ABSTRACT}

Soil as a critical element is an inalienable natural source for humankind. Especially after the industrial revolution, anthropogenic effects on soil were intensely observed. Moreover, the soil erosion rate increased progressively in the last century. For sustainable agricultural activities, evaluation of the soil loss rate is crucial. A couple of models based on Geographical Information System (GIS) (USLE, RUSLE, WEPP, EUROSEM) can calculate soil loss in $\mathrm{t} \mathrm{ha}^{-1}$ year $^{-1}$. Although these models have vulnerabilities, they still can provide general information about the distribution and amount of soil loss. These models integrate topography (DEM), soil, climate, land use, and land cover variables.

The topography of Turkey has been shaped under control Mediterranean and Continental climate and it has suffered from soil erosion. Southern Turkey, where the Taurus mountain belt lies, is characterized by high relief, which accelerates gravitational-related external processes. This region is also open for the warm-humid front from the Mediterranean sea, and these fronts have become conducive to orographic rainfall when reaching to the Taurus. This process also causes a high amount of sediment transportation along with surface runoff. So, these two variables (relief and climate) for erosion are epicenters of this study. As relief (slope) affects directly on erosion, DEM accuracy and resolution also play a crucial role in the asses of the topographic variables for soil loss models. As the DEM resolution increased, the performance of the DEM capability increased. From this point of view, in this study, we assessed the soil loss of the Akçay Basin located at Western Taurus Karadağ Mountain of the south-face, using Revised Universal Soil Loss Equation (RUSLE). Together with soil loss in the study area, DEM comparison was made between TanDEM-X12m., ALOS12.5m., and SRTM30m. DEMs in respect of the RUSLE method.

The study area differs from other areas (mostly located in the agricultural or gently slope regions) applied the RUSLE method while it's located in the mountainous terrain. Akçay Basin has relief more than $1800 \mathrm{~m}$. in the short range (15 km.) and narrow-steep valleys and canyons. From the climate viewpoint study, the area is characterized by the Mediterranean climate (average annual temp. $18.38^{\circ} \mathrm{C}$ and annual $862.3 \mathrm{~mm}$. precipitation), and orographic rainfall is also determined in the area. The lithology of the basin mainly composes of chert-limestone and dolomite.

The RUSLE model comprises five parameters that control soil loss. These are Rainfall and Runoff Erosivity Factor (R), Soil Erodobility Factor (12 samples taken), (C) Landuse and Landcover Factor (CORINE 2012 used), (LS) Slope Lenght and Steepness Factor, and (P) Support Practices. All of these parameters were calculated in the ArcGIS 10.4.1, SAGA GIS 7.2.0, and converted to factor maps; finally, the potential soil loss map was achieved. The LS factor was produced using TanDEM-X12m. DEM and then DEMs were compared utilizing the slope values of each DEM's slope values and validated with Unmanned Aerial Vehicle (UAV)-based DEM 1m.resolution.

According to the research conducted on soil loss by using RUSLE, factor maps and the final distribution of potential erosion loss map were created. In the study area, the R factor ranged from 403 to $601 \mathrm{t} \mathrm{ha}^{-1}$ year $^{-1}$, and the $\mathrm{K}$ factor values were between 0.010 and 0.079 $\mathrm{t} \mathrm{ha}^{-1}$ year $^{-1}$. Within the $\mathrm{C}$ factor, 14 types of CORINE classes were determined (43\%, mostly 323 Sclerophyllous vegetation and transitional woodland shrub). The LS factor values range from 0 to 174, and support practices are not observed in the area. Distribution of the potential soil loss focuses on high LS and R values, and the amount of soil loss is $0-167 \mathrm{t} \mathrm{ha}^{-1} \mathrm{year}^{-1}$.

In conclusion, it is determined that soil loss occurs in relief and climate control in the study area and according to the comparison result of DEM's TanDEM-X12m., represents the topography more accurately than the others. 


\section{GÍRIŞ}

Toprak erozyonu, tarımsal alanlar ve karasal ekolojik ortamlar üzerine en büyük tehditlerden biridir (Rui vd., 2018; Pimental, Harvey ve Resosudarmo, 1995). Toprak erozyonu, insanlığın günümüz problemi gibi görülse de, doğal kaynaklara ve çevreye tehdidi (Chen Hao vd., 2017; Rahman vd. 2009; de Vente vd. 2013) 1000 yıllarından günümüze dek 2 milyar hektar tarımsal potansiyele sahip alan kullanılamaz hale getirmiş (UNEP, 2012) ve erozyondan etkilenen tarımsal alanlar küresel ölçekte \%12 seviyelerine ulaşmıştır (Tanyaş, Kolat ve Süzen, 2017). Tarımsal planlama ve geliştirilecek projeksiyonlara veri sağlama bakımından toprak kaybı veya alanda gerçekleşen erozyonun niceliksel olarak bilinmesi karar vericiler için elzem veri tabanlarını oluşturmaktadır. Bu kapsamda dünya ölçeğinde yıllık 22 milyar ton toprak kaybı (antropojenik etki ile 57 milyar ton) (Simon vd., 2011), Türkiye'de ise yıllık maksimum 642 milyon ton toprak kaybı (ÇEM, 2018), karar vericiler için tarımsal sürdürülebilirliğin sağlanması adına dikkate alınması gereken verilerdir. Bilhassa son 50 yıllık süreçte antropojenik etkilerin mekân üzerine baskısı ve toprak bozulmasına (degredasyon) etkisi gözle görülür bir aşamaya ulaşmıştır. Söz konusu antropojenik degredasyonun, erozyon oranına etkisi Haiti (fazla) ve Dominik Cumhuriyeti (az) arasında (ortalama 50 ton ha $^{-1} \mathrm{ya}^{-1}$ fark) (Wuepper, Borrelli ve Finger, 2020) maksimum seviyelere ulaşmasında Haiti'nin 1920'li yıllarda başlayan ormansızlaştırma politikası etkili olmuştur.

1990’lı yıllardan günümüze literatürde sıklıkla tercih edilen SYM ve CBS tabanlı sayisal toprak erozyonu modelleri geliştirilmiştir. Bu modellerden, Evrensel Toprak Kaybı Eşitliği (USLE) (Wischmeier ve Smith, 1978) geliştirildikten sonra 1987 yılındaki revizyon ile Yenilenmiş Evrensel Toprak Kaybı (RUSLE), Su Erozyonu Kestirimi Projesi (WEPP) (Nearing vd., 1989), Avrupa Toprak Erozyonu Modeli (EUROSEM) (Morgan vd., 1998), Griffith Üniversitesi Erozyon Sistem Modeli (GUES) (Hairsine ve Rose, 1992) teknolojik gelişmeler sonucunda en çok tercih edilen modellerdendir.

Akdeniz Havzası'nda toprak erozyonu konularında arazinin kantitatif erozyon miktarını ortaya koymada RUSLE sıklıkla tercih edilen bir yöntemdir (Lanorte vd., 2019; Sahli vd. 2019; Fernández et al., 2010). Türkiye'de bir çok araştırmacı, çeşitli iklim, ve topoğrafik şartlara sahip alanlarda toprak erozyonunu tespit etme adına RUSLE yöntemini uygulamıştır (Tağıl, 2007; Erkal, 2012; Cürebal ve Ekinci, 2006; Erpul ve Saygın, 2012). İçerdiği parametrelerden kaynaklı olarak bu eşitlik, yüzeysel akışın kontrolünde gerçekleşen erozyonu ifade ederken, oyuntu erozyonu (gully), sediman depolanma alanlarının temsiliyeti bakımından zayıftır (Renard et al., 1997). Arazi koruma ve iyileştirme planlamaları için toprak kaybına yönelik sayısal bir veri sağlayan RUSLE, düşük eğimli topoğrafyalardaki $\left(<5^{\circ}\right)$ tarım alanlarında meydana gelen toprak erozyonunu tahmin etme adına geliştirilmiştir (Wischmeier ve Smith, 1978; Remortel vd., 2001; Lee K.H, 2006; Ganasri ve Ramesh, 2016). Geliştirilmesinden günümüze geçen sürede, CBS alanında ve SYM verilerinde gerçekleşen yenilikler, yöntemin mekânsal uygulanabilirlik ölçeğini ve performansını arttırmıştır.

Son 20 yılda, uzaktan algılama ve uydu teknolojileri, mekânsal çözünürlüğü santimetre boyutlarına kadar indirebilen çalışmalar mevcuttur (Llena, Vericat, Smith ve Wheaton, 2020; Akay, Özcan ve Şen, 2019). Bu gelişimin karşılığı, yer bilimlerinde ve özellikle jeomorfoloji çalışmalarında morfolojik özelliklerin deşifre edilmesinde önemli bir role sahiptir. Toprak erozyonu çalışmalarında, jeomorfolojik özelliklerin (lokal rölyef ve eğrisellik) denetlediği eğim ve eğim uzunluğu faktörü (LS) derecesi SYM çözünürlüğüne bağlı olarak değişkenlik göstermektedir.

Bu çalışmada, RUSLE yöntemi kapsamında Batı Toroslar'da Karadağ'ın güneyinde yer alan Akçay Havzası'nda meydana gelen toprak erozyonu hesaplanması ve TanDEM-X12m (DLR, 2016) SYM verisi tabanlı uygulanan yöntemin dağlık bir bölgede denenmesi hedeflenmiştir.

\section{2. ÇALIŞMA ALANI}

Akçay Havzası coğrafi olarak Akdeniz Bölgesi Teke Yöresi, Muğla ili Fethiye ilçesinin kuş uçumu yaklaşık 30 km kuzeykuzeydoğusunda konumlanmaktadır (Şekil 1a). Çalışma alanı Batı Toroslar dağ silsilesinde Karadağ'ın (2418 m) güneye bakan yamaçlarında Eşen Çayı'nın önemli bir alt havzasını $(185$ km² - 18500 ha) oluşturmaktadır. Tipik Akdeniz iklimi etkisinde yer alan çalışma alanı, Karadağ'ın da içinde yer aldığı Güneybatı Anadolu'da kış döneminde etkili olan yağış rejimi hakimdir ve burası Türkiye'nin Güney ve Batı bölgeleri içerisinde en fazla yağış alan bölümdür (Türkeş vd., 2008; Sarış vd., 2010; Bayrakdar vd., 2017). Çalışma alanını temsilen esas alınan Fethiye Meteoroloji İstasyonu (3 m) 1960-2016 yılları arasını kapsayan, yıllık ortalama sicaklık $18,38^{\circ} \mathrm{C}$ ve toplam yıllık ortalama yağış miktarı 862.3 mm'dir.

Akçay Havzası'nın jeolojik geçmişi Orta Triyas - Liyas'tan günümüz Kuvaterner - Holosen'e kadar uzanmaktadır. Çalışma alanındaki hakim litolojik birimi Kretase çörtlü kireçtaşları ile Liyas dolomitleridir (Şekil 1b). Kireçtaşı birimlerinin altında 


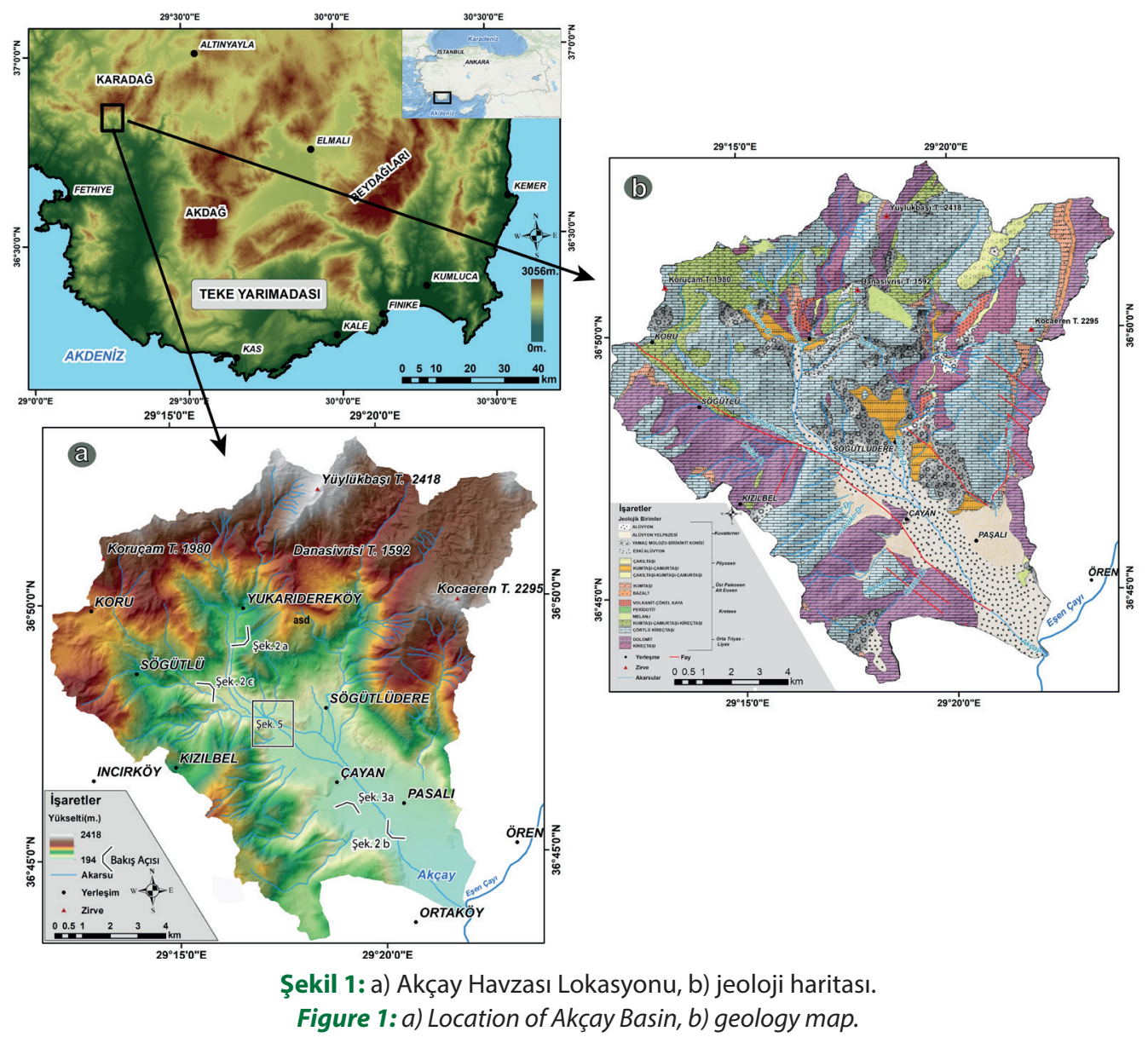

bulunan ve çalışma alanında yer yer yüzeylenen, genelde içerisinde kumtaşı ve şeyl bulunduran Elmalı Formasyonu erozyonun yoğunlaştı̆̆ı alanlarla karakterize olmaktadır. Likya Napları ve Beydağı otoktonu bölgenin şekillenmesinde önemli bir pay sahibidir ve çalışma alanı Gömbe ve Yavuz olmak üzere iki yapısal birimden oluşmaktadır (Şenel, 1997). Çalışma alanı ayrıca tektonik olarak aktif olan Burdur Fethiye Fay Zonu (BFFZ) üzerinde konumlanmaktadır (Yağmurlu, 2000).

Karadağ, en yüksek kısmı 2418 m olan ve 2300 m üzerinde birçok zirve ve 2100-2300 m seviyelerinde geniş karstik depresyonlar barındiran ve Pleyistosen buzullaşmalarının izlerinin net ve yaygın bir şekilde görüldüğü yüksek bir kütledir (Bayrakdar v.d. 2017). Bu kütlenin güney yamacını drene eden ve Eşen Çayı'nın önemli bir alt havzasını oluşturan Akçay, rölyefin kısa mesafede (5 km) 1700 m’yi bulduğu (Şekil 2a), yüksek eğim derecelerine $\left(>70^{\circ}\right)$ ulaşabilen (Şekil 7a), engebeli bir topoğrafyaya sahiptir.

Erozyonel süreçler ve yamaç formunu kütle hareketleri ve iklim elemanlarını etkileyen bakı (Istanbulluoglu, Yetemen, Vivoni, Gutiérrez-Jurado, ve Bras, 2008; Moreno-de las Heras

ve Gallart, 2016), çalışma alanının \%51'lik bir kısmı güney sektörlü bakı ile temsil edilmektedir. Görüm vd. (2017)’de Akdağ heyelanını açıkladıkları makalelerinde Likya Napları ve Beydağ1 otoktonu birimlerinin dokunak noktalarında meydana gelen kütle hareketleri çalışma alanında görülmektedir. Akçay’ın akış gösterdiği ana akarsu kanalı yamaçlarında meydana gelen heyelanlarla açı̆̆a çıkan killi birim üzerinde parmak (rill) ve oyuntu (gully) erozyonu gerçekleşmektedir (Şekil 2c). Yukarıdereköy batısında eğimin düşmeye başladığı ve Paşalı açıklarında Eşen Çayı'na katılan örgülü bir akış sergileyen Akçay, kum, kil, silt, çakıl boyutundaki alüvyonları ile Paşalı, Çayan, Ören arasında taşkın ovasını oluşturmaktadır (Şekil 2b).

Akçay havzasının toprak dağılışı incelendiğinde havzanın karakterize olduğu tür kırmızı akdeniz topraklarıdır (\%65). Bunun dişında havzada 6 farklı toprak tipi daha mevcuttur. Kireçtaşları üzerinde gelişen bu toprak türünü \%22'lik bir oranla kireçsiz kahverengi orman toprakları ve kahverengi orman toprakları izlemektedir (KHGM, 1999).

Havzada bitki örtüsü deniz seviyesi ile 1200m arasında maki ve Akdeniz orman sahası (pinus brutia, cedrus libani vs.) dağılışı 


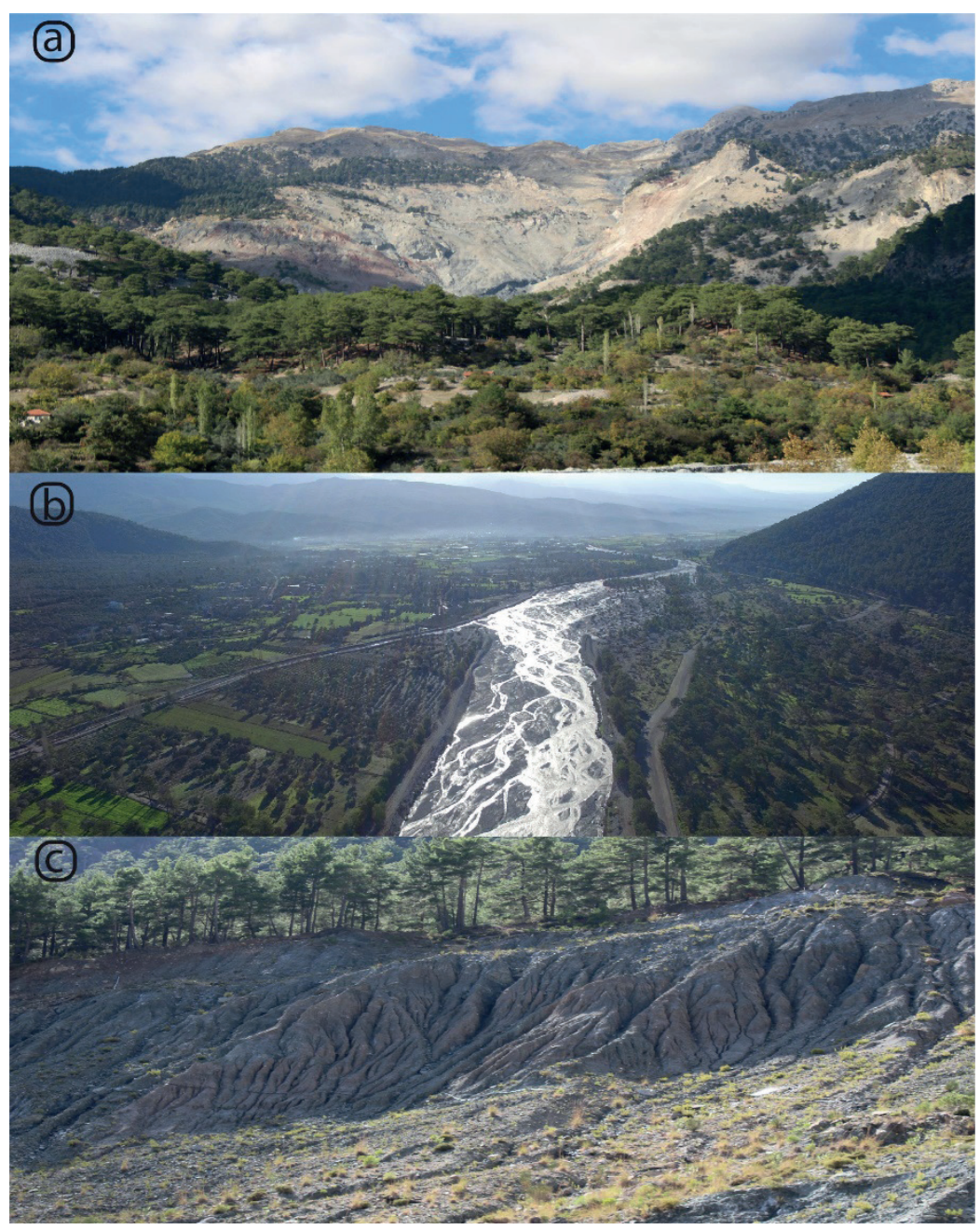

Şekil 2: Çalışma alanına genel bakış; a) rölyefin kısa mesafede artışı, b) örgülü akış desenine sahip Akçay, c) heyelan meydana geldikten sonra gevşek malzemeler üzerinde oluşan oyuntu erozyonu.

Figure 2: Overwiev of study area; a) increasing of relief in short-range, b) braided channel of Akçay, c) the formation of gully erosion on unconsolidated landslide materials.

gözlenirken bu seviyeden sonra yarı nemli yüksek dağ kuşağına geçilir ve 2000 m'ye kadar yüklesen bu kuşakta Pinus nigra (Karaçam), Cedrus Libani (Toros sediri) gibi türler gözlenmektedir (Seyhan, 1990). Kabaca 1800-2000 m eşiğinden sonra orman üst sınırına ulaşılmakta ve bitki örtüsü bu seviyeden sonra gözlenmemektedir.

\section{MATERYAL VE YÖNTEM}

\subsection{Rusle Yöntemi}

$\mathrm{Bu}$ yöntem, alanda potansiyel toprak kaybını yıllık olarak ortalama hektarda ifade eden beş ayrı parametrenin birbiriyle çarpılması ile elde edilmektedir (Wischmeier ve Smith, 1978). Bu parametreler 1) Yağış ve Akışın Erozyon Oluşturma Faktörü (R), 2) Toprağın Erozyona Duyarlılık Faktörü $(\mathrm{K}), 3)$ Eğim ve
Eğim Uzunluğu Faktörü (Ls), 4) Arazi Kullanımı ve Bitki Örtüsü Faktörü (C), 5) Toprak Koruma Önlemleri Faktörü (P)'dir. Aşağıda bu parametler kısaca açıklanmıştır.

\subsubsection{Yağış ve Akışın Erozyon Oluşturma Faktörü (R)}

Rusle yönteminin bir parametresi olan $\mathrm{R}$ faktör firtınalı bir dönemin en önemli iki göstergesi olan yağı̧s ve akışın erozivite gücünü yansitan bir parametredir (Wischmeier ve Smith, 1978). Ayrıca, arazi kaybı ve yüzey erozyonunu (sheet erosion) denetleyen en önemli faktörlerden biridir. $\mathrm{Bu}$ parametrenin erozyon gücünü, yeryüzüne düşen sağanak yağış karakterindeki ilksel düşen yağmur damlasının yaptığı etki ve devamında akışa geçen ve belirli bir yatağa kanalize olan akışın yapmış olduğu korazyon ve korozyon kuvveti belirlemektedir (Wischmeier ve Smith 1978). 
Yağış ve akışın yapmış olduğu toprak kaybını hesaplamak için Wischmeier ve Smith, 1978 'de belirtmiş olduğu formül alana yönelik detaylı (yağış şiddeti ve enerjisi) ve devamlı yă̆ış bilgileri gerekmektedir. Fakat bu değerler her meteoroloji istasyonu için mevcut olmadığı gibi, çalışma alanı dağlık bir bölgede bulunduğu için hesaplamalarda sorunlar çıkmaktadır. Detaylı ve devamlı yağı̧̧ bilgisi olmayan yerlerde hesaplamalardan doğacak zorlukları aşmak adına MFI (Düzeltilmiş Fournier İndeksi) formülü (Eş.1) geliştirilmiştir (Ferro, 1991).

\section{Eşitlik 1:}

$\mathrm{MFI}=\sum_{i=1}^{12} \frac{P i^{2}}{P i}$

$\mathrm{Pi}=$ Aylık ortalama yağı̧̧ verisi $(\mathrm{mm})$

$\mathrm{P}=$ Yıllık ortalama yăğ

Çalışma alanında $\mathrm{R}$ faktörü hesaplamak amacıyla MFI formülü kullanılmıştır. Kullanılan meteoroloji istasyonları verileri 1960-2016 yılını kapsayan Muğla, Fethiye ilçesine aittir. Yağış verilerini çalışma alanına yaymak adına Ardel 1969 ve Erinç 1996 önerdiği her 100 metrelik yükselti artışında 54mm. yağış artışını baz alan Schreiber formülü (Eş.2) baz alınmıştır. (Ardel vd., 1969; Erinç, 1996). Elde edilen sonuçlar, çalışma alanını kapsayan diğer çalışmadaki meteorolojik veriler (Yasan vd., 2019; Bayrakdar vd., 2020) ve WorldClim v2.0 (Fick vd., 2017) ile denetlenmiştir.

\section{Eşitlik 2:}

$\mathrm{Ph}=\mathrm{Po}+54 \mathrm{~h}$;

$\mathrm{Ph}$; yağış değeri bulunacak nokta

Po; ölçüm yapılan yağış miktarı

$\mathrm{h}$; hektometre cinsinden yükselti farkı

\subsubsection{Toprağın Erozyona Duyarlılık Faktörü (K)}

Toprağın içinde bulundurduğu bileşenlerden kaynaklanan ve dış kuvvetlere karşı erozyona uğrama hassasiyetine "erodobilite" denmektedir (Balc1, 1996). Toprağın erozyona duyarlılığı, bu bileşenlerinin içeriği ve kompozisyonu ile doğrudan ilişkilidir. Gerek ana kayanın üstünde gerekse de taşınarak buraya gelen, fiziksel ve kimyasal yollardan değişikliğe uğrayarak oluşan bu gevşek örtünün erozyona karş1 direncinin belirlenmesi gerekmektedir (Wischmeier ve Smith, 1978).

K faktör Yenilenmiş Evrensel Toprak Kaybı (RUSLE) eşitliğinde, $\% 9$ eğim ve 22,1 m eğim uzunluğundaki bir birim araziden, erozyon indisi olarak hektardan kaybolan toprağın ton olarak kaybını ifade etmektedir (Renard, 1997). K faktör hesaplanması için araziden 12 farklı lokasyondan zeminin $20 \mathrm{~cm}$ altından toprak burgusu ile toprak numunesi alınmıştır (Şekil 3a). Örnek lokasyonlarının seçerken başlıca litolojik farklılıklar gözetilmiştir. Arazinin engebeli yapısı, ulaşım zorlukları yaratmasından dolayı 6 farklı toprak (kahverengi orman toprakları, kırmızı akdeniz toprakları, kireçsiz orman toprakları, kireçsiz kahverengi topraklar, kolüvyal topraklar, alüvyal topraklar) türünden örnek alınmıştır. Alınan örnekler, İstanbul Üniversitesi Deniz Bilimleri ve İşletmeciliği Enstitüsü, Deniz Jeolojisi Laboratuvarında gerçekleştirilmiştir (Şekil 3b-c). Sediment örneklerinin ne şekilde taşındığı, taşıyıcının gücü ve depolanma ortamının enerjisi hakkında tane boyu dağılımı önemli veriler içermektedir. Özellikle ince tane boyutlu sedimentlerin erozyona daha çok uğradığı ve antropojenik kökenli kirleticileri de bünyesine alarak akarsular yoluyla denizlere taşıdığ 1 ve denizel ortamda depoladığ 1 bilinmektedir (Sarı vd. 2014 ve 2016). Bu nedenle K faktörünün hesaplaması ve ortam koşullarının yorumlanması için tane boyutu analizi (çakı1, kum, silt ve kil içeriği) İstanbul Üniversitesi Deniz

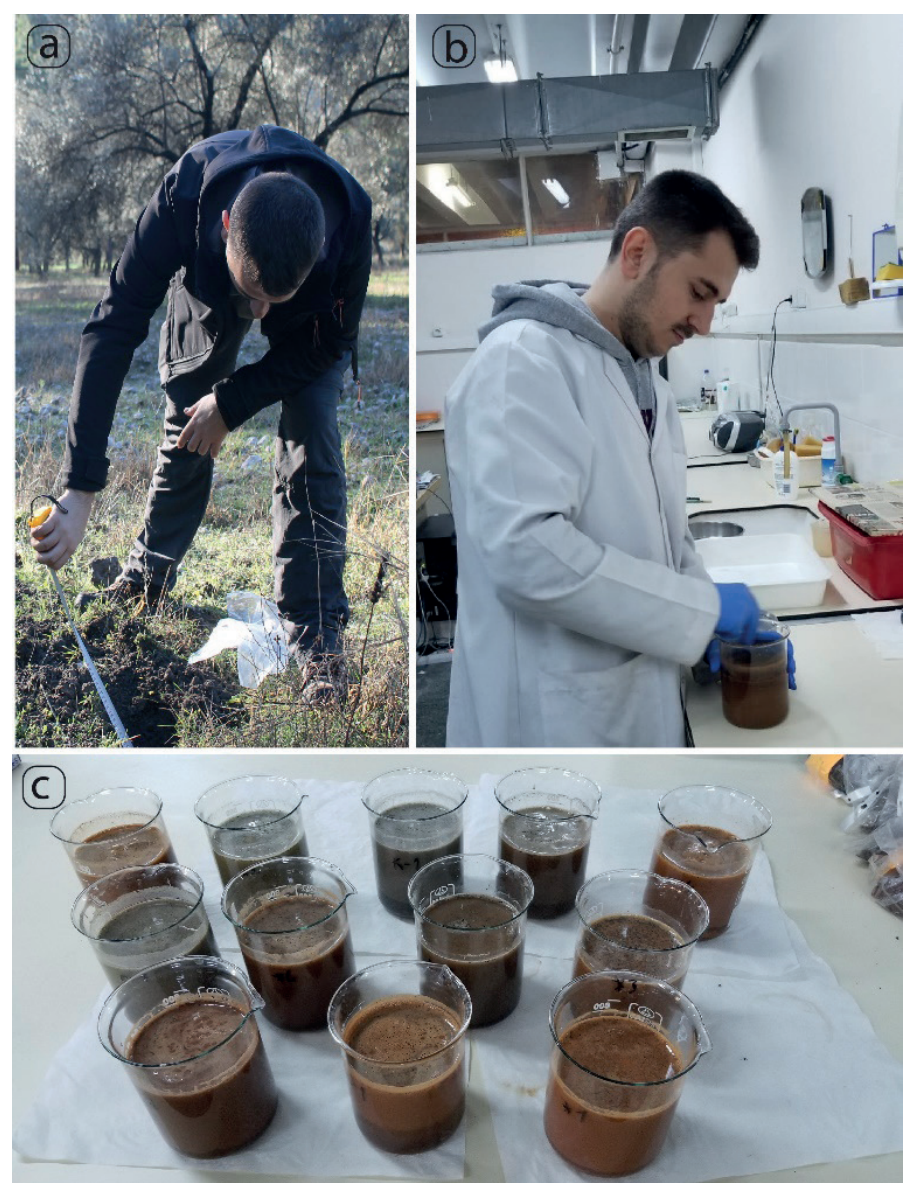

Şekil 3: a) Toprak örnek alımı ve b) ve c) Laboratuvar analizleri. Figure 3: a) Soil sampling, b) and c) Laborator analysis. 
Bilimleri ve İşletmeciğiEnstitüsü DenizJeolojisi Laboratuvarında Galehouse (1971) ve McManus (1991) metodu kullanılarak belirlenmiştir. Bu metoda göre toprak örneklerinin çakıl ve kum içeriği elek analizi (Retsch AS200 elek takımı), silt ve kil içeriği Sedigraph III aleti (Micromeritics) kullanılarak gerçekleştirilmiştir. Toprak içerisindeki organik karbon miktarının belirlenmesinde Walley-Blake yöntemi kullanılmıştır (Gaudette vd. 1974; Loring ve Rantala, 1992). Bu yöntem potasyum dikromat ile organik maddenin oksidasyonunu ve fazlalık dikromatın difanilamin indikatörlüğünde demir amonyum sülfat ile titrasyonunu içermektedir. Toplam organik karbon analizi için $0.5 \mathrm{~g}$ sediman örneği tartılarak $500 \mathrm{ml}$ 'lik erlene aktarılmıştır. Her bir örneğe $10 \mathrm{ml} 1 \mathrm{~N} \mathrm{~K}_{2} \mathrm{Cr}_{2} \mathrm{O}_{7}$ ve $20 \mathrm{ml}$ $\mathrm{H}_{2} \mathrm{SO}_{4}$ ilave edilmiştir. Örnekler 20-30 dakika süre boyunca ara ara çalkalanarak, $200 \mathrm{ml}$ saf su ile seyreltilmiştir. Ardından 10 $\mathrm{ml} \mathrm{H}_{3} \mathrm{PO}_{4}, 0.2$ gr NaF, $1 \mathrm{ml}$ difenilamin ilave edilmiştir. Daha sonra demir amonyum sülfat çözeltisi ile titre edilerek analizler tamamlanmıştır.

Çalışma alanında K faktörü hesaplamak adına, toprak tane boyutu ve organik madde parametrelerini baz alan Torri, 1997 yılında geliştirdiği formül kullanılmıştır (Eş.3). Hesaplanan K faktör değerleri ArcGıs 10.4.1 yazılımı ile alansal dağılımı gerçekleştirilip, haritalandırılmıştır.

\section{Eşitlik 3:}

$K=0.0293 \times\left(0.65 D_{G}+0.24 D_{G}{ }^{2}\right) \times E \times p\left\{-0.0021 \frac{o M}{f_{\text {clay }}}-0.0037\left(\frac{o M}{f_{\text {clay }}}\right)^{2}-4.02 C+1.72 f_{\text {clay }}{ }^{2}\right\}$

Denklemde $D_{G}$;

$D_{G}=-3.5 f_{\text {sand }}-2.0 f_{\text {silt }}-0.5 f_{\text {clay }}$

\subsubsection{Eğim ve Eğim Uzunluğu Faktörü (Ls)}

Yöntem içerisinde sayısal yükselti modeli aracılığıyla üretilen ve alanın morfometrik kimliğini deşifre eden özelliklerinden biri olan LS faktör, arazinin eğimi ve eğim uzunluğunu ifade eder ve erozyon hesaplamalarında önemli bir parametredir. LS faktörü, diğer coğrafik faktörlerin sabit kabul edildiği, 22,13 m uzunluğunda ve \%9 eğimi olan bir arazideki toprak kaybı miktarını temsil etmektedir. LS değerleri mutlak değerler değildir fakat 22,13 m uzunluğunda ve \%9 eğime sahip bir arazideki LS değeri 1'dir (Wischmeier ve Smith 1978). Genel olarak Ls faktörün artışı, eğim boyunca kümülatif akışını eğim boyunca yoğunlaşmasına sebep olduğu için erozyon miktarı ile doğru orantılıdır (Prasannakumar et al., 2011). Çalışmada Ls faktör üretiminde, TanDEM-X12m SYM verisinden SAGA 7.2.0 ve ArcGıs 10.4.1 yazılımları ile hesaplanmış ve haritalandırılmıştır.

\subsubsection{Arazi Kullanımı ve Bitki Örtüsü Faktörü (C)}

Arazi kullanımı ve bitki örtüsü faktörü (C), erozyonun hızını ve şiddetini belirleyen kritik faktörlerden biridir. Bitki örtüsü, araziden yararlanma şekilleri (tarım, yerleşme, maden aktiviteleri vs.) toprak kaybının dengelenmesinde doğal ya da beşerî bir faktör olurken, tam tersi hızlanmasinda da etkin rol oynamaktadır. Arazinin hangi amaçla kullanıldığı amaçlayan C faktör (Renard, 1997), son y1llarda gelişen uydu teknolojileri ve uzaktan algılama sistemleri ile hesaplanabilmektedir. Bu çalışmada da, Avrupa Komisyonu ve Avrupa Çevre Ajansı'nın "Copernicus" ortak projesinin "Land Monitor Service" adı altında Avrupa ölçeğinde oluşturduğu bitki örtüsü ve arazi kullanımı bilgilerini içeren bir veri kaynağı olan CORÍNE2012 verisi kullanılmıştır. Avrupa kıtası ölçeğinde hazırlanan veri, Türkiye'yi de kapsamaktadır. Yöntem kapsamında faktör haritası elde edilebilmesi adına CORİNE2012 verisinden çalışma alanının olduğu bölüp kesilip, haritalandırılmıştır. C faktör değerlerinin hesaplanmasında Angeli, 2004 ve Bakker, 2008'in yapmış oldukları çalışmalardan yararlanmıştır.

\subsubsection{Toprak Koruma Önlemleri Faktörü (P)}

Toprak kaybını önlem adına çalışmalar genelde tarımsal potansiyelin fazla olduğu alanlarda uygulanmaktadır. Bu önlemler dahilinde arazinin engebeliliğine, eğim derecesi bağlı olaraktan, izohipsler doğrultusunda sürüm, teraslama, şeritsel ekim gibi yöntemler geliştirilmiş̧ir. Bu teknikler, yüzeysel akışın akış şeklini, derecesini veya yönünü değiştirerek veya yüzeysel akışın miktarını ve hızını azaltarak erozyonu etki etmektedir (Renard ve Foster, 1983; Gülşen, 2014). Faktörün Rusle eşitliğindeki değer aralığı 0-1 arası değişmektedir. Çalışma alanında toprak koruma önlemleri ile ilgili bir çalı̧̧ma gerçekleştirilmediği için erozyon hesaplamasına 1 değeri ile girmiştir.

\section{BULGULAR}

Çalışma alanında meydana gelen toprak kaybını tespit etme adına, RUSLE yönteminin baz aldığı faktörler hesaplanmış ve haritalanmıştır. Hesaplanan faktörler sonucunda Akçay Havzası'nda meydana gelen toprak kaybı tespit edilmiş̧ir. Aşağıda sırasıyla hesaplanan faktörler ve toprak kaybı bulguları belirtilmiş̧tir.

Rusle yöntemi kapsamında hesaplanmış olan ilk faktör R faktördür. Yağışın ve akışın erozyona katkısını ton $\mathrm{ha}^{-1} \mathrm{y}^{1} \mathrm{l}^{-1}$ cinsinden hesaplayan faktörün çalışma alanı içindeki dağılışı alansal olarak kuzeye doğru yükseltinin artmasıyla doğru orantılıdır (Şekil 4a). R faktör değeri yükseltinin en az olduğu Paşalı çevresinde (200 m), Yüylükbaşı Zirvesi (2418 m) arasında 
403 ile 601 ton ha $^{-1} \mathrm{yll}^{-1}$ değerlerinde değişmektedir. Schreiber formülüne (Ardel vd.,1969; Erinç, 1996) göre 200 m yüksekliğe sahip çalışma alanın en düşük kesiminde ortalama yıllık yağış miktarı $1024 \mathrm{~mm}$, bu değer orman üst sınırında 1834mm'ye kadar çıkmaktadır. $\mathrm{R}$ faktör alansal dağılımı incelendiğinde çalışma alanında, 1800 m'den sonra orman üst sınırını aşılması, 1800 m - 2418 m aralığı çalışma alanında R faktörün maksimum (601 ton/ha/yıl) değerlerle karakterize olmasına ve oransal olarak en geniş alanı oluşturmasına neden olmuştur.

Eğim ve eğim uzunluğu baz alan Ls faktör değerleri çalışma alanında 0-174 değerleri arasında değişkenlik göstermektedir. Ls faktörün alansal olarak incelendiğinde eğim derecelerinin $0^{\circ}-2^{\circ}$ arası değiştĭgi akarsu yatağının genişlediği taşkın ovasında en
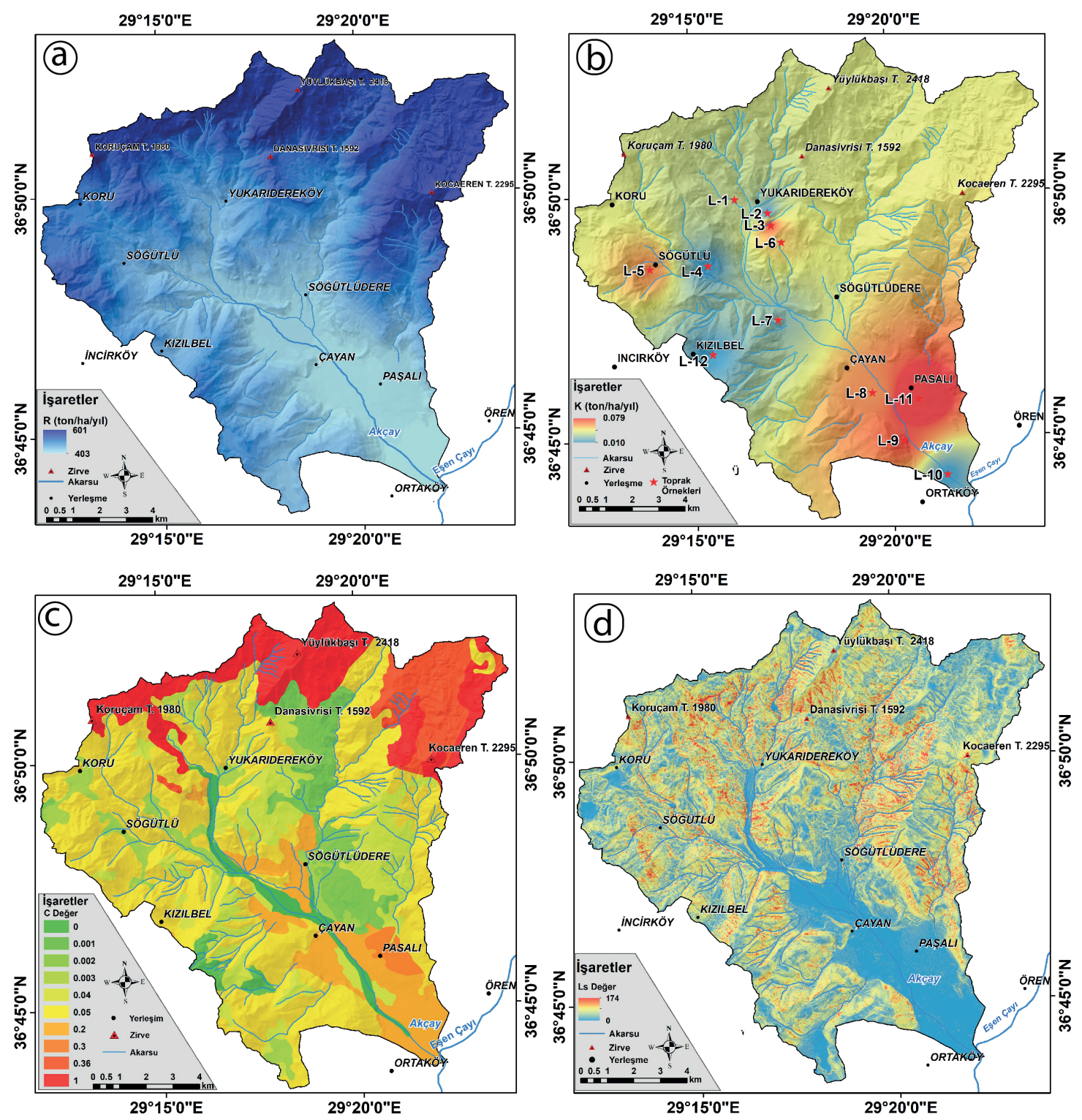

Şekil 4: RUSLE parametreleri dağılış haritaları; a) R faktör dağılışı, b) K faktör dağılışı, c) C faktör dağılışı, d) Ls faktör dağılışı,

Figure 4: The distrubition maps of RUSLE parameters; a) R factor distrubition, b) K factor distribution, c) C factor distribution d) Ls factor distrubition. 
analizleri sonucunda $\mathrm{K}$ faktör değerleri hesaplanmıştır. 0.010 ile 0.079 değerleri (Şekil $4 \mathbf{b}$ ) arasında değişen $\mathrm{K}$ faktör değerleri Doğan, 2002 yapmış olduğu erodobilete değerlerine göre "Çok az aşınabilir" ve "Az aşınabilir" sınıfına girmektedir.

Toprak erozyonu konusunda bir diğer önemli faktör olan Arazi Kullanımı ve Bitki Örtüsü Faktörü (C), CORİNE2012 verisinden yararlanarak hesaplanmıştır. Bu veriye göre çalışma alanında 14 farklı arazi kullanımı türü tespit edilmiştir. Bu faktör değerleri 0 (minimum) ile 1 maksimum) arasında değişmektedir. Çalışma alanında Sert Yapraklı Ormanlar (323) ve Çayırlar (324) 0.5 değeri en yoğun $(\% 43)$ gözlenen tür olarak tespit edilmiştir (Şekil 4d).

Yukarıda bahsedilen toprak koruma yöntemleri kapsamında çalışma alanında yapılan arazi çalışmaları, çeşitli hava fotoğraflarının incelenmesi ve bölgede yaşayan halk ile yapılan görüşmeler sonucunda toprak koruma önlemleri tespit edilememiştir. Toprak kaybı denkleminde 0-1 arası bir değer aralığına sahip olan P faktör eğer çalışma alanında herhangi bir koruma aktivitesi bulunmamasında durumunda eşitliği değiştirecek bir etkiye sahip değildir. Bu etkiden dolayı çalışma alanında $P$ faktör denkleme 1 değeri ile dahil edilmiştir.

Çalışma alanında Rusle yöntemi kapsamında TanDEM$\mathrm{X} 12 \mathrm{~m}$ verisi ile hesaplanan toprak kayb1 0-167 ton $\mathrm{ha}^{-1} \mathrm{yll}^{-1}$ arası değişmektedir (Şekil 6a, Tablo 1). Toprak kaybı değerlerinin $>167$ ton ha $^{-1}$ yll $^{-1}$ olduğu bölümler görülmektedir, fakat bu alanlar oransal olarak limitli $(<\% 0.05)$ bir alanla temsil edilmektedir. Çalışma alanın büyük bir çoğunluğu (\%94) 0-85 ton/ha/yıl toprak kaybının gerçekleștiği bölgede yer almaktadır. Akçay havzasının özellikle güney ve batı bölümü $0-8$ ton ha ${ }^{-1}$ $\mathrm{y}^{1}{ }^{-1}$ toprak kaybı ile çalışma alanın \%58'lik bir alanını kaplamaktadır. Yükseltinin arttığı çalışma alanın kuzeyinde bitki örtüsünden yoksun alanlar, eğim derecesinin akarsu vadilerinde eğimin $>30^{\circ}$ üzeri oldu alanlar, bölgede erozyon miktarı $>56$ ton $\mathrm{ha}^{-1} \mathrm{yll}^{-1}$ ile karakterize olmaktadır. Havzada, ortalama toprak kaybı 28 ton ha ${ }^{-1} \mathrm{yll}^{-1}$ olarak tespit edilmiştir.

Meydana gelen toprak kaybının diğer SYM veri kaynaklarına oranla nasıl bir değişikliği gösterdiğini ortaya koyma adına SRTM30m ve ALOS12.5m SYM verilerinden potansiyel toprak kaybı hesaplamaları gerçekleştirilmiştir. Elde edilen sonuçlara göre; SRTM30m (Şekil 6c) verisi ile hesaplanan toprak kayb1 0 - 139 ton ha ${ }^{-1} \mathrm{yll}^{-1}$ dır. Fakat bu aralık içinde 0- 59 ton ha ${ }^{-1} \mathrm{yll}^{-1}$ aralığ1 gerçekleşen toprak kaybının \%93 $\left(172 \mathrm{~km}^{2}\right)^{\prime}$ 'lik bir kısmını temsil etmektedir. ALOS12.5m (Şekil 6b) verisi ile hesaplanan toprak kaybı değerleri $0-147$ ton $\mathrm{ha}^{-1} \mathrm{yll}^{-1}$ arasında değişmektedir. $\mathrm{Bu}$ değerler için de $0-58$ ton $\mathrm{ha}^{-1} \mathrm{yll}^{-1}$ arası çalışma alanın toplam \%94 $\left(174 \mathrm{~km}^{2}\right)$ 'ünü temsil etmektedir.

Çalışma alanında elde edilen sonuçları denetleme adına, yüksekliğin 1. dereceden türevi olan eğimin erozyonla olan pozitif korelasyonundan dolayı, çalışma alanından insansız hava aracı (IHA) ile $1 \mathrm{~km}^{2}$ lik test alanından $1 \mathrm{~m}$. çözünürlüğünde SYM üretilmiştir (Şekil 5). TanDEM-X12m, SRTM30m. ve ALOS12.5m SYM verilerinden elde edilen eğim derecelerinin, (İHA) ile üretilen $1 \mathrm{~m}$. çözünürlükteki SYM'den üretilen eğim dereceleriyle korelasyonu sirayla, $\mathrm{r}=0.32, \mathrm{r}=0.23, \mathrm{r}=0,12$ olarak tespit edilmiştir. Bu sonuca göre TanDEM-X12m ile üretilen eğim doğruya en yakın sonuca ulaşmış ve yukarıda belirtilen eğim-toprak kaybı korelasyonu sonucunda toprak kaybını en doğruya yakın temsil gücüne ulaşmıştır.

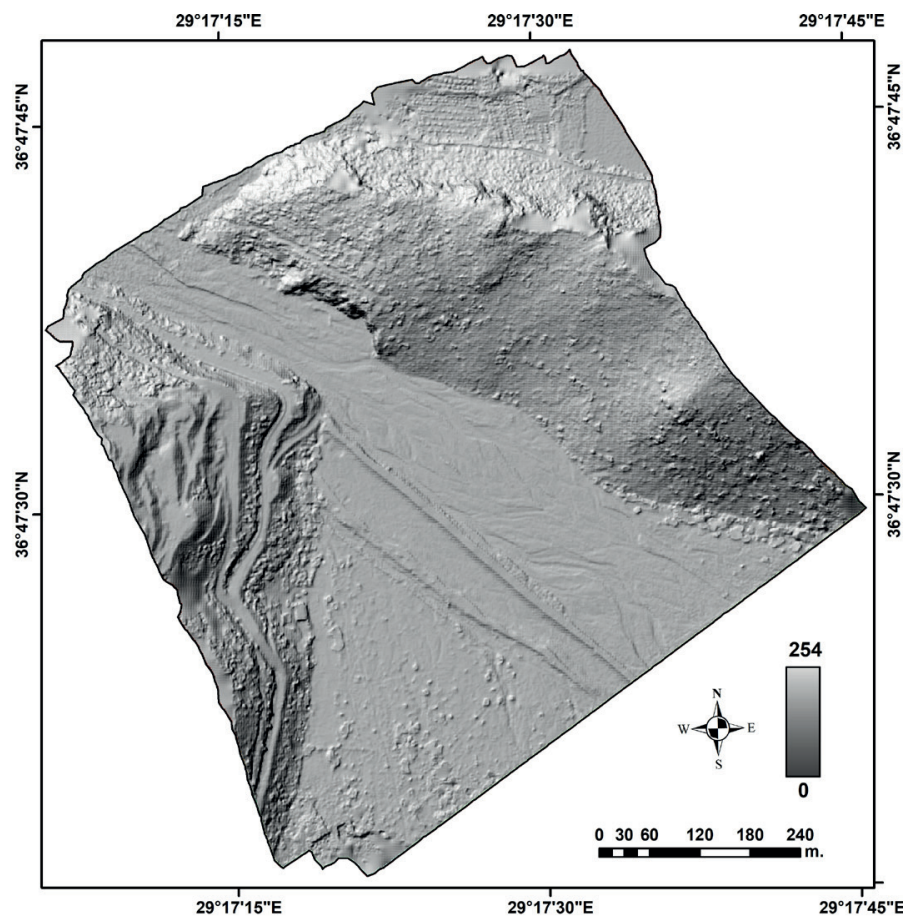

Şekil 5: Mekansal doğrulama için İHA ile üretilen $1 \mathrm{~m}$ çözürlüğündeki SYM'den oluşturulan gölgeli kabartma haritası.

Figure 5: The hillshade map producing from UAV-based $1 \mathrm{~m}$ SYM for spatial validation.

Tablo 1: TanDEM-X12m'den üretilen toprak kaybı miktarları. Table 1: TanDEM-X12m-based soil loss amounts.

\begin{tabular}{lll}
\hline Toprak Kaybı Miktarı (ton/ha/yıl) & Alan (\%) & Alan $\left.\mathbf{( k m}^{\mathbf{2}}\right)$ \\
\hline $\mathbf{0 - \mathbf { 8 }}$ & 58 & 107.3 \\
$\mathbf{8}-\mathbf{2 7}$ & 19 & 35.15 \\
$\mathbf{2 7}-\mathbf{5 6}$ & 13 & 24.05 \\
$\mathbf{5 6 - \mathbf { 8 5 }}$ & 7 & 12.95 \\
$\mathbf{8 5}-\mathbf{1 1 9}$ & 2 & 3.7 \\
$\mathbf{1 1 9}-\mathbf{1 6 7}$ & 1 & 1.85 \\
$\mathbf{1 6 7}<$ & 0 & 0 \\
Toplam & 100 & 185 \\
\hline
\end{tabular}




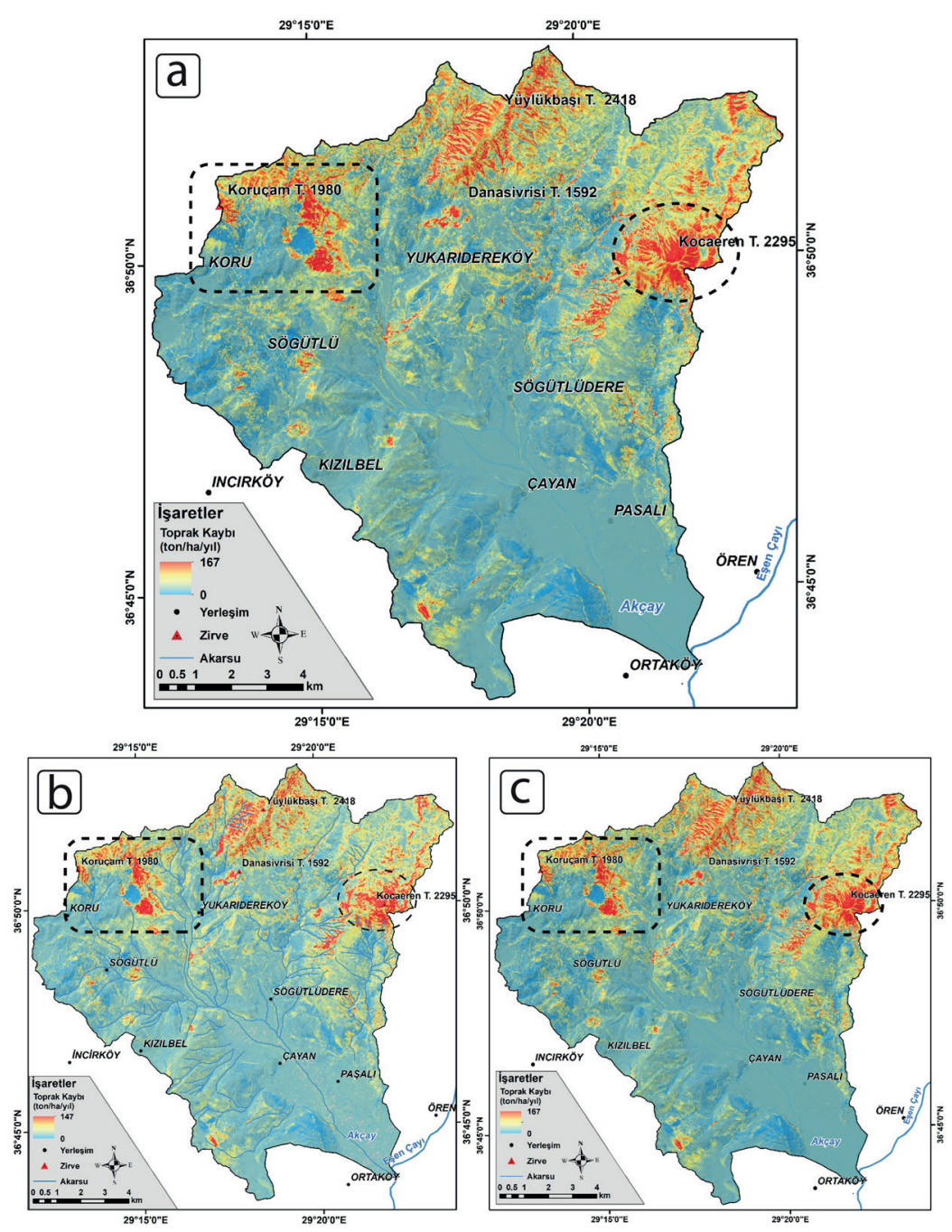

Şekil 6: Akçay Havzası toprak kaybı mekansal dağılışı; a) TanDEM-X12m., b) Alos12.5m., c) SRTM30m.

Figure 6: The spatial distribution soil loss of Akçay Basin; a) TanDEM-X12m., b) Alos 12.5m., SRTM30m.

\section{TARTIŞMA}

TanDEM-X12m SYM verisi tabanlı gerçekleştirilen çalışmada toprak kaybı potensiyelinin dağılımı tespit edilmiştir. Toprak kaybının arttığı alanlar ile eğimin arttığı alanlar arasında pozitif bir korelasyon tespit edilmiştir $(\mathrm{r}=0.62)$. Bu sonuca destek olarak, Şekil 7a'da K-G yönlü çekilen Swath Profil incelendiğinde erozyon, eğim, yükselti değerlerinin çalışma alanının kuzey bölgesinde yoğunlaştığı ve eğim erozyon korelasyonunu sergilemektedir. Ayrıca yine aynı profilin güneyinde eğim derecelerinin artışı net bir şekilde görülmesine (kuzeye yakın değerler) rağmen erozyon miktarının aynı oranda artmaması, buradaki R faktör (yağış düşük) ve C faktörde (bitki örtüsü artışı) düşük değerleri erozyonu kontrol eden faktörler olarak ortaya çıkmaktadır. Akçay yukarı akaçlama havzasında "V" şekilli vadilerde yamaçların eğimlerin yüksek olmasına rağmen, bu yamaçların boyunun kısa olması, LS faktördeki eğim uzunluğu parametresini etkilemesinden dolayı değerlerin limitlenmesine neden olmaktadır. Erozyonel süreçlerin gelişimi jeolojik ve litolojik özellikler ile de yakından ilişkilidir. Kütle hareketleri sonucunda açığa çıkan killi birimler (Yeşilbarak formasyonu) üzerinde oyuntu erozyonu (gully) oluştuğu ve erozyonel süreçlerin hızlandığı tespit edilmiştir (Şekil 2c).

RUSLE yöntemi kullanılarak yürütülen toprak erozyonu çalışmalarında elde edilen sonuçlar incelendiğinde: Halfalı Deresi akaçlama havzasında (Kahramanmaraş) ortalama yıllık toprak kaybı 12.8 ton ha $^{-1} \mathrm{y}^{-1}{ }^{-1}$ (Abız, 2014), Çamlıdere Barajı Havzası'nda (Ankara) ortalama yıllık toprak kaybı 7.3 ton $\mathrm{ha}^{-1} \mathrm{y}^{-1}{ }^{-1}$ Y $1 \mathrm{lmaz}$, 2006), Büyük Menderes Havzası'nda yürütülen toprak erozyonu çalışmasında ise 9.9 ton $\mathrm{ha}^{-1} \mathrm{y}^{l^{-1}}$ toprak kaybı tespit edilmiştir

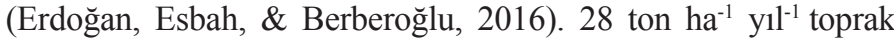
kaybı ile çalışma alanı, Türkiye'nin çeşitli bölgelerinden gösterilen ortalama toprak kaybı miktarlarının üzerindedir. $\mathrm{Bu}$ durumun 
oluşmasında çalışma alanının, dağlık bir bölgede yer almasından dolayı yüksek eğim derecelerine sahip olması ve Akdeniz üzerinden gelen nemli hava kütlelerine karşı orografik bariyer oluşturmasından kaynaklandığı söylenebilir.

Erozyonel süreçlerin başlatılması ve kaynak alanından depolanma alanına hareketliliğinde iklim elemanları sürecin yönetilmesinde etkin bir rol oynamaktadır. Yüzey erozyonunun önemi RUSLE yöntemi için R faktör yağgş ile temsil edilmektedir ve yağışın şiddetinin ve süresinin artışı toprakta meydana gelen erozyonu arttırmaktadır. Akçay havzasında $\mathrm{R}$ faktörün artışı yükseltinin artışıyla orantılı bir şekilde gerçekleşen yağışın miktarı ve şiddeti zemin üzerinde yaptığı yağmur damlaların yaptığı erozyonun (splash erosion) arttığı alanlara denk düşmektedir. Aynı zamanda bu alanlar yağış oluşum şekli olarak "Yamaç Yağışları" ile karakterize olması yağışıı kinetik enerjisini arttırmakta ve erozyonu pozitif etkilemektedir. R faktöre göre erozyonun düştüğü alanlar Akçay Havzası'nın güneyi ve yükseltinin en az ve dolayısıyla yağışın göreceli az olduğu alanları temsil etmektedir. $\mathrm{K}$ faktör değerlerinin alansal dağglımı incelendiğinde (Şekil 4b) eğimin düştüğü, Akçay'ın taşkın alanına denk gelen kolüvyal topraklar üzerinden alınan örneklerde erozyon şiddeti göreceli olarak daha yüksek çıkmaktadır. $\mathrm{Bu}$ durumun ortaya çıkmasında örnek alınan lokasyonda toprak tekstüründeki tane boyutunun büyük $(>0.5$ mm boyutundaki kum ve çakıl $\% 75$ 'ten fazla) olması, ve bununla beraber organik madde içeriğinin düşük olması $(<\% 2)$ neden olmaktadır (Tablo 2). Yöntemde parametreler arasında ağılık katsayıları kullanılmamasından dolayı $\mathrm{K}$ faktörünün yüksek olduğu alanlar, eğim derecesi ve yağış akış faktörünün düşük olduğu alanlara denk gelmesine rağmen sonuçları etkileyen bir parametre olarak görülmektedir. Özellikle bu durum Bakırçay Havzası'nda gerçekleştirilen toprak kaybı çalışmasında da $\mathrm{R}$ faktör ve $\mathrm{C}$ faktörün düşük olmasına rağmen $\mathrm{K}$ faktörün, alanda erodobilitesinin yüksek olması, genel toprak kaybı miktarını yükseltmektedir (Danacıoğlu ve Tağıl, 2017). Ayrıca sahadan alınan örneklerle gerçekleştirilen analizler, toprak türlerinin aynı olduğu durumda dahi toprak içeriğinin değişiklik göstermesi(tekstür, organik madde) sebebiyle, $\mathrm{K}$ faktörün alansal değişkenliğini göstermektedir. Bu değişkenlik, Şekil $4 \mathbf{b}$ 'de kırmızı akdeniz toprakları (T) üzerinden alınan L-1 (0.003 ton $\left.\mathrm{ha}^{-1} \mathrm{yll}^{-1}\right), \mathrm{L}-2(0.01$ ton/ha/yll $)$ ve L-3 (0.6 ton $\left.\mathrm{ha}^{-1} \mathrm{yll}^{-1}\right)$ örneklerinin yaklaşı $3 \mathrm{~km}$ mesafede görülmektedir.

Karadağ'ın güney sektöründe ve Akdeniz'den gelen nemli hava kütlelerinin ilk karşılaştı̆̆ dağlık bir bölgede yer alan Akçay Havzası, erozyon değerlerinin yükselti ve eğim ile kontrol edilmesi erozyonel alansal dağıllışınıda kontrol etmektedir. Eğim ve bağlantılı olarak erozyonun arttığı çalışma alanının kuzey kuzeydoğu kesimleri eğim derecelerinin $>30^{\circ}$ üzerine çıktığı, yağışın $\operatorname{arttığı~}(>1000 \mathrm{~mm}$.) ve bitki örtüsünün seyrek veya olmadığı anakayanın yüzeylendiği bölgelerdir. Erozyon değerlerinin düştüğü alanlar, çalışma alanında Akçay'ın taşkın ovası, genelde eğim derecelerinin $0-10^{\circ}$ arası değiştiği bölgeler, bitki örtüsü orman formasyonunda bulunduğu ve göreceli yağışın düşük olduğu $(<1000 \mathrm{~m})$ bölgeler ile karakterize olmaktadır.

Akçay Havzası'nda tarımsal faaliyetlerin yapıldığı alanlar, Akçay'ın alt akaçlama havzasında yoğunlaşmaktadır (Şekil 2b). Tarımın yoğunlaştığı alanlar, R (Şekil 4a), Ls (Şekil 4d) gibi RUSLE parametrelerinin en düşük olduğu alanlar gibi görünsede, toprak analizlerinde yüksek erozyon değerleriyle temsil edilen alanları meydana getirmektedir (Şekil 4b). Bu oranların ortaya çıkmasında Akçay'ın kaynak alanı ve Eşen Çay ile birleştiği nokta arasında mesafenin kısa olması $(\sim 15 \mathrm{~km})$, lokal rölyefin yüksek olması $(>1700 \mathrm{~m})$ gibi faktörlerin, tarımsal arazilere iri taneli ( $>2 \mathrm{~mm}$ ) sedimanları (gravel ve boulder) taşınması sebep olmaktadır. $\mathrm{Bu}$ yüzden tarımsal alanların taşkın ovasında konumlanması, tarımsal aktiviteler için belirtilen sebeplerden ötürü ayrı bir risk etmeni oluşturmaktadır.

Tablo 2: Toprak analizi için alınan örneklerin organik madde, tane boyu ve $\mathrm{K}$ faktör analiz sonuçları tablosu. Table 2: The table of $\mathrm{K}$ factor analysis results of soil samples' organic material and grain size.

\begin{tabular}{|c|c|c|c|c|c|c|c|}
\hline Örnek Lokasyonu & Toprak Türü & $\%$ Organik Madde & \%Çakıl & \%Kum & \%Silt & $\%$ Kil & K Faktör \\
\hline L1 & Kırmızı Akdeniz Toprakları(T) & 1.47 & 44.69 & 54.96 & 0.11 & 0.21 & 0.03 \\
\hline L2 & Kırmız Akdeniz Toprakları(T) & 0.02 & 83.72 & 16.26 & 0.01 & 0.01 & 0.01 \\
\hline L3 & Kırmız Akdeniz Toprakları(T) & 2.15 & 58.7 & 40.77 & 0.25 & 0.28 & 0.06 \\
\hline L4 & Kireçsiz Kahverengi Topraklar(U) & 1.48 & 58.71 & 41.19 & 0.03 & 0.08 & 0.01 \\
\hline L5 & Kırmız Akdeniz Toprakları(T) & 3.92 & 42.49 & 57.07 & 0.19 & 0.25 & 0.05 \\
\hline L6 & Kireçsiz Kahverengi Topraklar(U) & 1.47 & 29.07 & 69.22 & 0.41 & 1.3 & 0.04 \\
\hline L7 & Kireçsiz Orman Toprakları(N) & 3.22 & 50.43 & 49.37 & 0.05 & 0.16 & 0.02 \\
\hline L8 & Kolüvyal Topraklar(K) & 1.56 & 34.44 & 64.74 & 0.28 & 0.55 & 0.05 \\
\hline L9 & Kırmız Akdeniz Toprakları(T) & 2.74 & 53.42 & 45.59 & 0.3 & 0.68 & 0.06 \\
\hline L10 & Alüvyal Topraklar(A) & 1.62 & 27.06 & 72.36 & 0.36 & 0.23 & 0.01 \\
\hline $\mathrm{L} 11$ & Kolüvyal Topraklar(K) & 0.94 & 56.38 & 42.95 & 0.36 & 0.31 & 0.08 \\
\hline L12 & Kırmızı Akdeniz Toprakları(T) & 1.74 & 33.35 & 66.64 & 0 & 0.01 & 0.01 \\
\hline
\end{tabular}




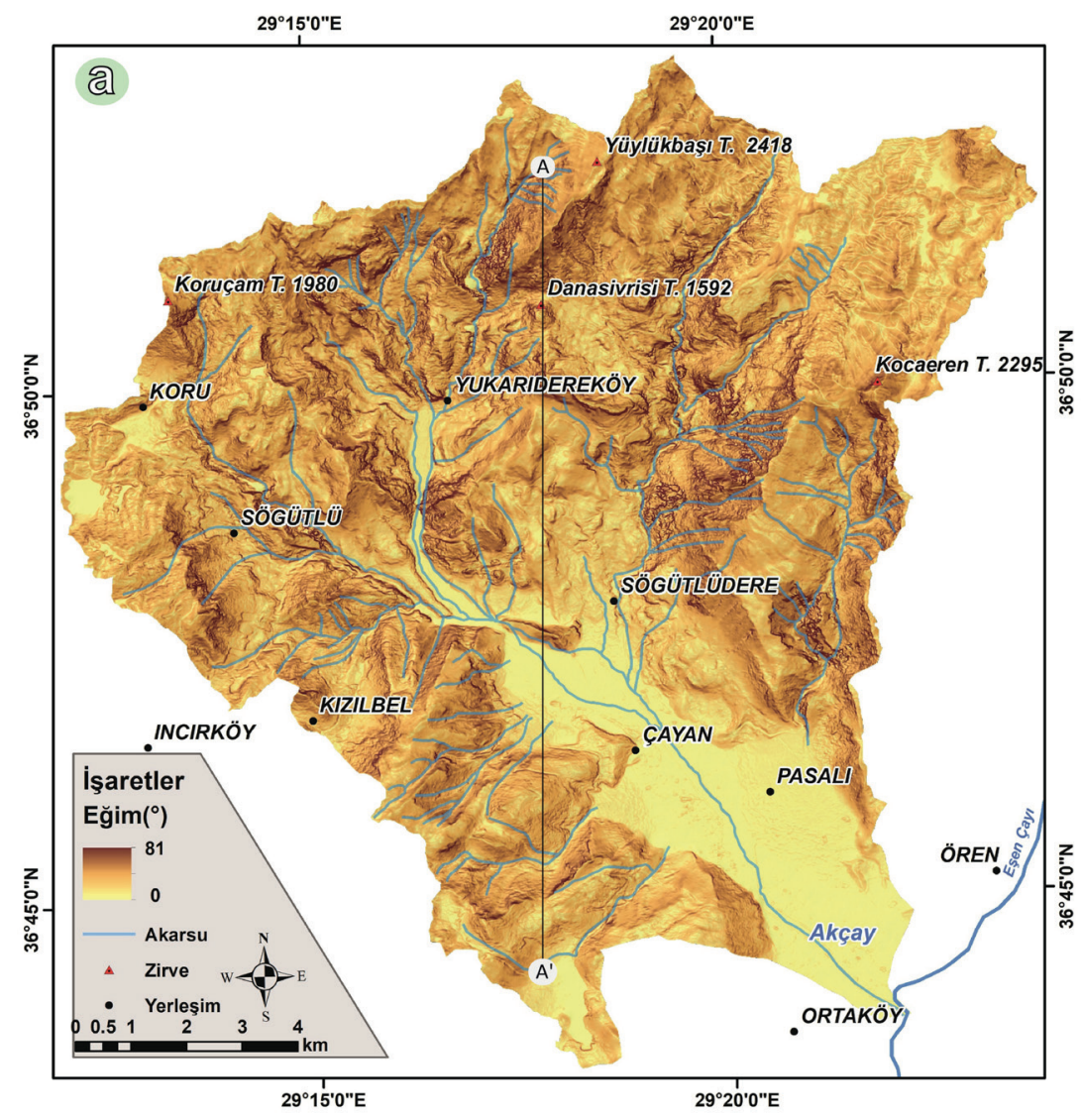

(b)

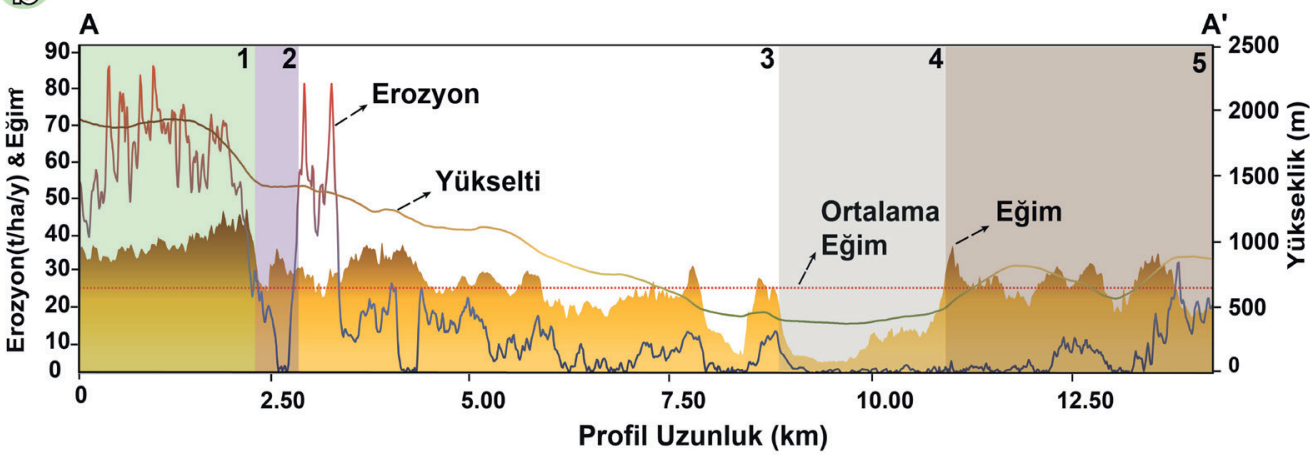

Şekil 7: Akçay Havzası'nda yükselti, eğim değerleri, ve erozyonun karşılaştırılması, a) Akçay Havzası eğim haritası, b) A, A ' hattı, TanDEM-X12m verisine dayalı eğim, ortalama eğim, yükselti ve erozyon swath profilidir (1 km yarı çapı). 1) Yükselti ve erozyonun uyum gösterdiği bölge 2) eğim derecesinin ani düşüşü ve erozyonun beraber düşüşü, 3) geçiş zonu, 4) akçay vadi tabanı, 5) eğimin artış göstermesi fakat erozyonun diğer parameterlerden (R) dolayı limitli kaldığı zon.

Figure 7: The multiple comparison of the altitude, slope gradient, and the amount of soil loss a) the slope gradient map of the Akçay Basin, b) A, A ' transection is the TanDEM-X12m-based swath profile (1 km radius) of slope deg. $\left({ }^{\circ}\right)$, mean slope deg., elevation and erosion. 1) Erosion and elevation conformity, 2) decreasing slope deg. suddenly and erosion, 3) trasition zone, 4) valley floor, 5) increasing slope deg. but erosion is limited due to other parameters $(R)$.

\section{SONUÇ}

Akçay Havzası'nda TanDEM-X12m SYM verisi tabanlı gerçekleştirilen toprak erozyonu belirleme çalışma kapsamında, yüksek toprak kaybının (>50 ton $\mathrm{ha}^{-1} \mathrm{yll}^{-1}$ ) meydana geldiği bölgeler genelde eğim derecesinin yüksek $\left(>30^{\circ}\right)$, yağ 1 ş ve akış faktörünün yüksek olduğu (>800m) alanlarla temsil edildiği tespit edilmiştir. Dağlık bir bölgede yer alan Akçay Havzası'nın ortalama toprak kayb1 28 ton $\mathrm{ha}^{-1} \mathrm{y}^{-1} \mathrm{l}^{-1}$ tespit edilmiştir ve bu sonucu ortaya çıkmasında, eğimin ani değişikliği, kısa mesafede rölyefin hızlı artışı ve Akdeniz üzerinden gelen nemli hava kütlelerine bir bariyer görevi görmesiyle yağışın miktar ve 
şiddeti arttırması erozyonu kontrol eden faktörlerin başında geldiği düşünülmektedir. Kısa mesafede ve hatta aynı toprak türü üzerinde değişen $\mathrm{K}$ faktör, RUSLE yöntemi için toprak analizlerinin önemini doğrulamıştır. Yapılan çalışma ile SYM'ler arasında erozyonu yansıtma gücü, eğim dereceleri (LS faktörü yansıtan) baz alınması sonucunda en fazla TanDEM$\mathrm{X} 12 \mathrm{~m}$ SYM verisinde tespit edilmiştir. Bu sonuç ile beraber SYM verilerinin çözünürlüğünün artmasıyla, topoğrafik süreçlerle ilişkili olarak, toprak erozyonu konusunda da gerçeği yansıtma kabiliyetinin arttığı ve gelecek erozyon çalışmaları için yüksek çözünürlük mekansal verilerle çalışmanın gerekliliği ortaya konmuştur. $\mathrm{Bu}$ sonuçlarla beraber çalışma alanında toprak erozyonu problemi varlığı kantitatif olarak da ortaya konmuştur.

Teşekkür: Bu çalışma, Farklı Veri Kaynakları Temelinde Akçay Havzası'nda Rusle (3d) Yönteminin Değerlendirilmesi adlı tez çalışmasının bir parçası olarak ortaya çıkmıştır ve İstanbul Üniversitesi Bilimsel Araştırma Projeleri Koordinasyon Birimi tarafindan desteklenmiştir. Proje numarası: Syl-2019-33217. Aynı zamanda bu çalışmada TÜBİTAK ÇAYDAG 117Y391 nolu projesi kapsamında kurulan Söğütlüdere meteroloji istasyonu verilerinden faydalanılmıştır. Yazarlar meteoroloji verisi ve arazi çalışması konusundaki desteklerinden dolayı TÜBITAK'a ve TanDEM-X (12m) verisi temininin gerçekleştirildiği kurum Alman Uzay Ajansı (DLR)'a katkılarından dolayı teşekkürü bir borç bilirler.

Hakem Değerlendirmesi: Dış bağımsız.

Çıkar Çatışması: Yazarlar çıkar çatışması bildirmemiştir.

Finansal Destek: İstanbul Üniversitesi, BAP birimi tarafından desteklenmiş̦tir. Proje no: SYL-2019-33217.

Peer-review: Externally peer-reviewed.

Conflict of Interest: The authors have no conflict of interest to declare.

Grant Support: This study was funded by Istanbul University with the project number: SYL-2019-33217.

\section{KAYNAKCA/REFERENCES}

Abız, B. (2014). Kahramanmaraş Halfali Deresi Yağiş Havzasinda Uzaktan Algilama Teknikleri Ve Rusle Yöntemi Kullanilarak Erozyon Risk Haritasinin Oluşturulmasi. (Yüksek Lisans Tezi). Kahramanmaraş Sütçü İmam Üniversitesi Fen Bilimleri Enstitüsü, Kahramanmaraş.

Akay, S. S., Ozcan, O., \& Sen, O. L. (2019). Modeling morphodynamic processes in a meandering river with unmanned aerial vehicle-based measurements. Journal of Applied Remote Sensing.

Angeli, L. (2004). Alutazione del rischio erosione applicazioni del modello RUSLE.Centro Ricerche Erosione Suolo. Centro Ricerche Erosione Suolo.

Ardel, A. Kurter, A., Dönmez, Y. (1969). Klimatoloji Tatbikatı. İstanbul: İ̈̈ Yay. No: 1123.

Bakker, M. G. (2008). The response of soil erosion and sediment export to land-use change infour areas of Europe: the importance of landscape pattern. Geomorphology.

Bayrakdar, C., Çıl̆ğı, Z., \& Sarış, F. (2017). Karadağ'da Pleyistosen Buzullaşmaları, Batı Toroslar, 3Türkiye. Türkiye Jeoloji Bülteni.
Bayrakdar, C., Çılğın, Z., \& Keserci, F. (2020). Traces of late quaternary glaciations and paleoclimatic interpretation of Mount Akdağ (Alanya, $2451 \mathrm{~m}$ ), Southwest Turkey. Mediterranean Geoscience Reviews, 135-151.

Cürebal, İ., \& Ekinci, D. (2006). Kızılkeçili Deresi Havzasında CBS Tabanlı Rusle (3d) Yöntemiyle Erozyon Analizi. Türk Coğrafya Dergisi.

ÇEM. (2018). DEMIS Türkiye Su Erozyonu Istatistikleri, Teknik Özet. Ankara: Çölleşme ve Erozyonla Mücadele Genel Müdürlüğü Yayınları.

CHEN, H., Oguchi, T., \& WU, P. (2017). Assessment for soil loss by using a scheme of alterative sub-models based on the RUSLE in a Karst Basin of Southwest China. Journal of Integrative Agriculture, 16(2), 377-388. doi:10.1016/s2095-3119(16)61507-1

Danacığlu, Ş., \& Tağıl, Ş. (2017). Bakırçay Havzasi'nda Rusle Modeli Kullanarak Erozyon Riskinin Değerlendirmesi. Balıkesir Üniversitesi Sosyal Bilimler Enstitüsü Dergisi, 1-18.

DLR. (2016). TanDEM-X ground segment DEM products specification document TD-GS-PS-0021 v.3.1. DLR.

Erdoğan, M. A., Esbah, H., \& Berberoğlu, S. (2016). Erosion Risk Mapping Using Rusle With Gis: Case Study Of Büyük Menderes River Basin Of Turkey. Int. J. Of Safety And Security Eng., 6(2), 132-140.

Erinç, S. (1996) Klimatoloji Metotları. İstanbul: Çantay Kitbevi.

Erkal, T. (2012). Çobanlar Havzasi'nda (Afyonkarahisar) Toprak Erozyonunun Değerlendirilmesi. The Journal of Academic Social Science Studies, 543-562.

Erpul, G., \& Saygın, S. D. (2012). Ülkemizde Toprak Erozyonu Sorunu Üzerine: Ne Yapmalı? Toprak Bilimi ve Bitki Besleme Dergisi, 26-32.

Fernández, C., Vega, J. A., \& Vieira, D. C. S. (2010). Assessing soil erosion after fire and rehabilitation treatments in NW Spain: Performance of rusle and revised Morgan-Morgan- Finney models. Land Degradation and Development, 21(1), 58-67. https://doi.org/10.1002/ldr.965

Ferro, V. G. (1991). Isoerosivity and erosion risk map for Sicily. Hydrology Science Journal, 36, 549-564.

Fick, S. E. and R. J. Hijmans, 2017. WorldClim 2: new $1 \mathrm{~km}$ spatial resolution climate surfacesfor global land areas. International Journal of Climatology, 37(12), 4302-4315.

Galehouse, J. S. (1971). Sedimentation Analysis, Procedures in sedimentary petrology. New York: Wiley-Interscience

Ganasri, B. P., \& Ramesh, H. (2016). Assessment of soil erosion by RUSLE model using remote sensing and GIS - A case study of Nethravathi Basin. Geoscience Frontiers, 7(6), 953-961. https:// doi.org/10.1016/j.gsf.2015.10.007

Gaudette, H. E., Flight, W. R., Tonner, L., Folger, D. G. (1974). An inexpensive titration method for the determination of organic carbon in recent sediments. Journal of Sedimentary Research, 44, 249-253.

Görüm, T., Bayrakdar, C., Uğur, A., \& Resul, Ç. (2017). Geomorphology of the Mount Akdag landslide, Western Taurus Range (SW Turkey), Journal Of Maps, 165-172. https://doi.org/10.1080/17445647.2017 .1280424 
Gülşen, M. (2014). Eber Havzasında (Afyonkarahisar) Toprak Erozyonunun Değerlendirilmesi. (Yüksek Lisans Tezi). Afyon Kocatepe Üniversitesi Sosyal Bilimler Üniversitesi Afyonkarahisar

Hairsane, P. B. and Rose, C. W. (1992b). Modelling water erosion due to overland flow using pyhsical principles, 2. rill flow. Water Resour. Res.

Istanbulluoglu, E., Yetemen, O., Vivoni, E. R., Gutiérrez-Jurado, H. A., \& Bras, R. L. (2008). Eco-geomorphic implications of hillslope aspect: Inferences from analysis of landscape morphology in central New Mexico. Geophysical Research Letters, 35(14), 1-6. https:// doi.org/10.1029/2008GL034477

KHGM. (1999). Muğla İli Arazi Varlı̆̆ı. Ankara: T.C. Başbakanlık Köy Hizmetleri Genel Müdürlüğü Yay.

Lanorte, A., Cillis, G., Calamita, G., Nolè, G., Pilogallo, A., Tucci, B., \& De Santis, F. (2019). Integrated approach of RUSLE, GIS and ESA Sentinel-2 satellite data for post-fire soil erosion assessment in Basilicata region (Southern Italy). Geomatics, Natural Hazards and Risk, 10(1), 1563-1595.

Lee G. S., L. K. (2006). Scaling effect for estimating soil lossin the RUSLE model using remotely sensed geospatial data in Korea. Hydrology \& Earth System Sciences Discussions.

Llena, M., Vericat, D., Smith, M. W., \& Wheaton, J. M. (2020). Geomorphic process signatures reshaping sub-humid Mediterranean badlands: 1. Methodological development based on High Resolution Topography. In Earth Surface Processes and Landforms. https:// doi.org/10.1002/esp.4821

McManus, J., 1988. Grain size determination and interpretation, (Techniques in Sedimentology, Editör: Tucker, M.,). Oxford,: Blackwell Scientific Publication, 63-85.

Moreno-de las Heras, M., \& Gallart, F. (2016). Lithology controls the regional distribution and morphological diversity of montane Mediterranean badlands in the upper Llobregat basin (eastern Pyrenees). Geomorphology, 273, 107-115.https://doi.org/10.1016/j. geomorph.2016.08.004

Morgan, R. P. C., Quinton, J. N., Smith, R. E., Govers, G., Poesen, J. W. A., Auerswald, K., Chisci, G., Torri, D., and Styczen, M. E. (1998). The European Soil Erosion Model (EUROSEM): A dynamic approach for predicting sediment transport from fields and small catchments. Earth Surface Processes and Landforms, 23, 527-544.

Nearing, M. A., Foster, G. R., Lane, L. J., and Finckner, S. C., 1989. A process based soil erosion model for USDA water erosion prediction technology. Transactions of the American Society of Agricultural Engineers, 32, 1587-1593.

Pilogallo, G., Nolè, F., Amato, L., Saganeiti, M., Bentivenga, G., Palladino, F., Scorza, B., Murgante, G., Las Casas. (2019). Geotourism as a Specialization in the Territorial Context of the Basilicata Region (Southern Italy). Geoheritage, 11(4), 1435-1445.

Pimentel, D., Harvey, C., Resosudarmo, P., Sinclair, K., Kurz, D., McNair, M., ... Blair, R. (1995). Environmental and Economic Costs of Soil Erosion and Conservation Benefits. Science, 267(5201), 1117-1123. doi:10.1126/science.267.5201.1117
Price, S. J., Ford, J. R., Cooper, A. H., \& Neal, C. (2011). Humans as major geological and geomorphological agents in the Anthropocene: the significance of artificial ground in Great Britain. Philosophical Transactions of the Royal Society A: Mathematical, Physical and Engineering. Sciences, 369(1938), 1056-1084. doi:10.1098/ rsta.2010.0296

Rahman, M. R., Shi, Z. H., Chongfa, C. (2009). Soil erosion hazard evaluation - An integrated use of remote sensing, GIS and statistical approaches with biophysical parameters towards management strategies. Ecological Modelling, 220, 1724-1734.

Renard, K. G. (1997). Predicting Soil Erosion By Water: A Guide To Conservation Planning With The Revised Universal Soil Loss Equation (RUSLE). Washington, DC: Agriculture Handbook, USDA.

Renard, K. G. (1983). Soil conservation: principles of erosion by water. American Society of Agronomy. Agronomy, a series of monographs; no. $23,155-176$.

Sahli, Y., Mokhtari, E., Merzouk, B. et al. (2019). Mapping surface water erosion potential in the Soummam watershed in Northeast Algeria with RUSLE model. J. Mt. Sci. 16, 1606-1615.

Sarı, E., Ünlü, S., Apak, R., Balc1, N. \& Koldemir, B., (2014). Distribution and Contamination of Heavy Metals in the Surface Sediments of Ambarli Port Area (Istanbul, Turkey). Ekoloji, 23, 1-9.

Sarı, E., Cukrov, N., Franciskovic-Bilinski, S., Kurt, M. A. \& Hallı, M., (2016). Contamination assessment of ecotoxic metals in recent sediments from the Ergene River, Turkey. Environmental Earth Sciences 75 .

Sariş, F., Hannah, D. M., \& Eastwood, W. J. (2010). Spatial variability of precipitation regimes over Turkey. Hydrological Science Journal.

Sayhan, S., (1990). Teke Yarımadasının Bitki Coğrafyası. (Basılmamış Doktora Tezi) - İstanbul Üniversitesi, Sosyal Bilimler Enstitüsü.

Şenel, M. (1997). "1:100.000 Ölçekli Türkiye Jeoloji Haritaları No:2 Fethiye - L8 Paftas1. Ankara: Maden Tetkik ve Arama Genel Müdürlüğü.

Tağıl, Ş. (2007). Tuzla Çayı Havzası (Biga Yarımadası) CBS-Tabanlı RUSLE Modeli Kullanarak Arazi Degradasyonu Risk Değerlendirmesi. Ekoloji, 11-20.

Tanyaş, H., Kolat, Ç., \& Süzen, M. L. (2015). A new approach to estimate cover-management factor of RUSLE and validation of RUSLE model in the watershed of Kartalkaya Dam. Journal of Hydrology.

Torri, D., Poesen, J., \& Borselli, L. (1997). Predictability and uncertainty of the soil erodibility factor using a global dataset. CATENA, 31(12), 1-22. doi:10.1016/s0341- 8162(97)00036-2

Türkeş, M., Koç, T., \& Sariş, F. (2009). Spatiotemporal variability of precipitation total series over Turkey. International Journal of Climatology, 29(8), 1056-1074. doi:10.1002/joc.1768

de Vente J, Poesen J, Verstraeten G, Govers G, Vanmaercke M, Van Rompaey A, Arabkhedri M, Boix-Fayos C. 2013. Predicting soil erosion and sediment yield at regional scales: Where do we stand? Earth-Science Reviews, 127, 16-29. 
Wischme1er, W. H. (1978). Predicting rainfall erosion losses. A Guide to conservation planning, United States Department of Agriculture, Agricultural Research Service (USDA-ARS) Handbook, No.537. Washington DC.: United States Government Printing Office.

Wuepper, D., Borrelli, P., \& Finger, R. (2020). Countries and the global rate of soil erosion. Nature Sustainability, 3(1), 51-55. https://doi. org/10.1038/s41893-019-0438-4

UNEP, (1986). Sands of change: why land becomes desert and what can be done about it

UNEP Brief \#2, United Nations Environment Programme, Nairobi, Kenya.
Yağmurlu, F. (2000). Burdur fayının sismotektonik. Batı Anadolu'nun Depremselliği Sempozyumu, (s. 143-151). İzmir.

Yasan, O. vd., (2019). Dağlık alanların iklim özelliklerini belirlemede cbs tabanlı enterpolasyon yöntemlerinin kullanımı: Batı Toroslar Örneği. Akköprü E., Döker F. M., (Ed.), Coğrafya araştırmalarında Coğrafi Bilgi Sistemi kullanımı kitabı içinde (s. 197- 215). Ankara: Pegem Akademi.

Y1lmaz, E. (2006). Çamlıdere Baraji Havzasinda Erozyon Problemi Ve Risk Analizi. (Yüksek Lisans Tezi). Ankara Üniversitesi Sosyal Bilimler Enstitüsü, Ankara. 
